\begin{tabular}{|c|c|c|c|}
\hline DE & \multirow{3}{*}{$\begin{array}{l}\text { DE GRUYTER } \\
\text { OPEN }\end{array}$} & $\begin{array}{l}\text { HUNGARIAN JOURNAL OF } \\
\text { INDUSTRY AND CHEMISTRY }\end{array}$ & 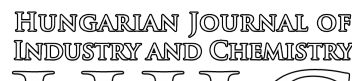 \\
\hline & & Vol. 43(1) pp. 7-13 (2015) & \\
\hline & & $\begin{array}{l}\text { hjic.mk.uni-pannon.hu } \\
\text { DOI: } 10.1515 / \text { hjic-2015-0002 }\end{array}$ & $a \sqrt{6}$ \\
\hline
\end{tabular}

\title{
MULTI-ELEMENTAL INDUCTIVELY COUPLED PLASMA-OPTICAL EMISSION SPECTROSCOPIC CALIBRATION PROBLEMS OF THE SEQUENTIAL EXTRACTION PROCEDURE FOR THE FRACTIONATION OF THE HEAVY METAL CONTENT FROM AQUATIC SEDIMENTS
}

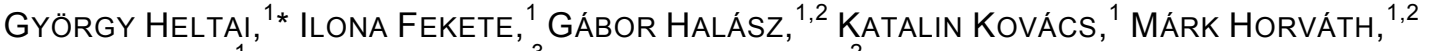 \\ ANITA TAKÁCS, ${ }^{1}$ NORBERT BOROS, ${ }^{3}$ AND ZOLTÁN GYÖRI ${ }^{2}$ \\ ${ }^{1}$ Department of Chemistry and Biochemistry, Szent István University, Pater K. u. 1., Gödöllö, 2100, \\ HUNGARY \\ ${ }^{2}$ Regional Knowledge Centre, Szent István University, Pater K. u. 1., Gödöllö, 2100, HUNGARY \\ ${ }^{3}$ Department of Environmental and Chemical Engineering, University of Debrecen, Ótemető u. 2-4., \\ Debrecen, 4028, HUNGARY
}

\begin{abstract}
For the characterisation of the environmental mobility of heavy metal contamination in aquatic sediments, the EU Bureau of Reference has proposed a fractionation by sequential extraction procedure. For its validation, the CRM-701 sample is available containing $\mathrm{Cd}, \mathrm{Cr}, \mathrm{Cu}, \mathrm{Ni}, \mathrm{Pb}$, and $\mathrm{Zn}$. In this paper, the matrix-matched calibration problems are presented. A multi-elemental inductively coupled plasma-optical emission technique is employed for the detection of heavy metals in the extracts. It was established that the sensitivities are strongly influenced by the extractants, which causes significant matrix effects: the sensitivities are strongly influenced by the solvents applied in extraction steps; the summarised recoveries show an acceptable agreement with the certified values; however, in the individual extraction steps for certain elements significant differences may occur due to the neglected interferences. Therefore, further optimisation is required utilising the flexible line selection possibility offered by the HORIBA Jobin Yvon ACTIVA-M instrument.
\end{abstract}

Keywords: fractionation, sequential extraction, multi-elemental ICP-OES, matrix-matched calibration, heavy metal contamination, sediments

\section{Introduction}

Environmentally toxic elements, such as heavy metals, are the most significant inorganic pollutants. The role of different chemical elements in food production has been an important question of agrochemical research since the middle of the nineteenth century. Numerous extraction methods have been developed for determining biologically available fractions of nutritionally relevant elements in soils. Environmental researchers have confronted similar problems over the last few decades of the twentieth century in characterising the human- and eco-toxicological impacts of increasing heavy metal pollution. This challenge has created new requirements for analytical methodology and contributed to the development of speciation analytical chemistry. This scientific discipline provides the foundation for the evaluation of toxicological impacts of chemical elemental species detectable in environmental systems [1,2]. In such procedures, the original physico-chemical structural forms of chemical elements present in the system must be preserved during sampling and sample preparation. Then, appropriate separation methods must be applied before element specific analytical detection (Fig.1).

*Correspondence: heltai.gyorgy@mkk.szie.hu
The European Union established the European Virtual Institute for Speciation Analysis in 2002 for promoting cooperation, collection, reviewing, and discussion of information and knowledge related to chemical speciation analysis (www.speciation.net). Attention was drawn to the mobility and biological impact of heavy metals in environmental systems influenced by their chemical speciation. Biological risk assessment of contaminated areas therefore requires the total speciation of all chemical elements present in the system. However, due to the complex structure of solid environmental samples (e.g. soils, sediments, gravitation dust, mining waste, etc.), these analytical tasks in practice cannot be fully completed. As a compromise, the fractionation of the heavy metal content according to environmental mobility and estimation of biological availability by sequential extraction procedures have become the main research approaches. Papers published in this area and their citations exponentially increased in the period of 1995

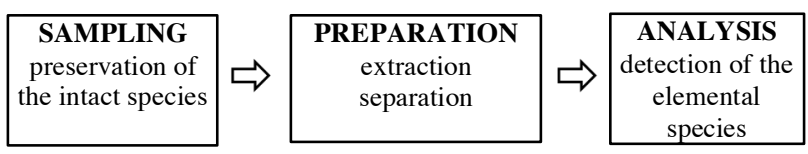

Figure 1. Scheme of the speciation analysis procedure. 


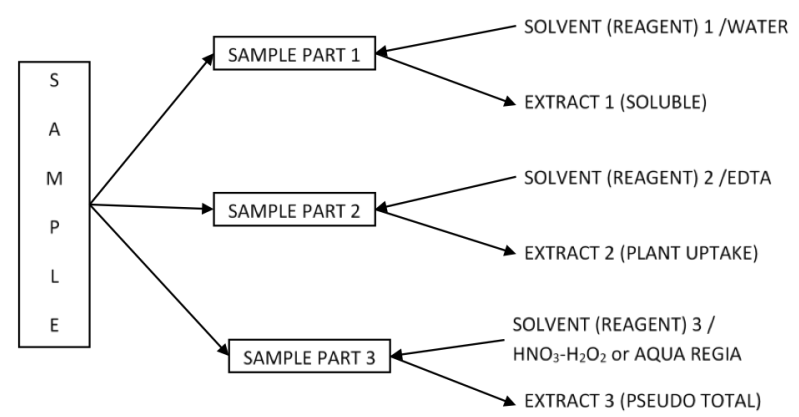

Figure 2. Strategy of serial single-step extractions.

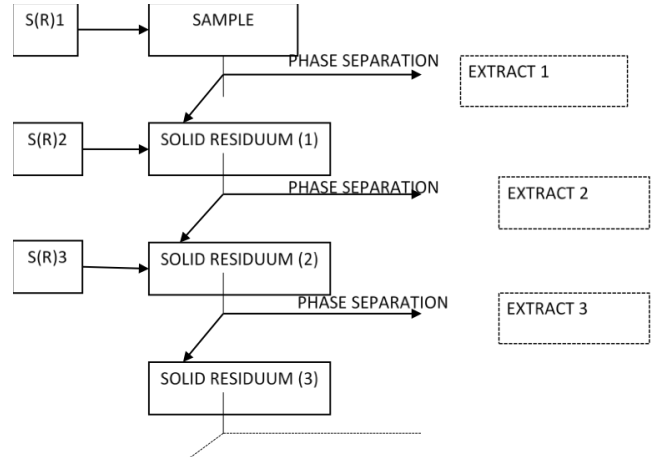

Figure 3. Strategy of sequential extractions (S(R) stands for SOLVENT(REAGENT)).

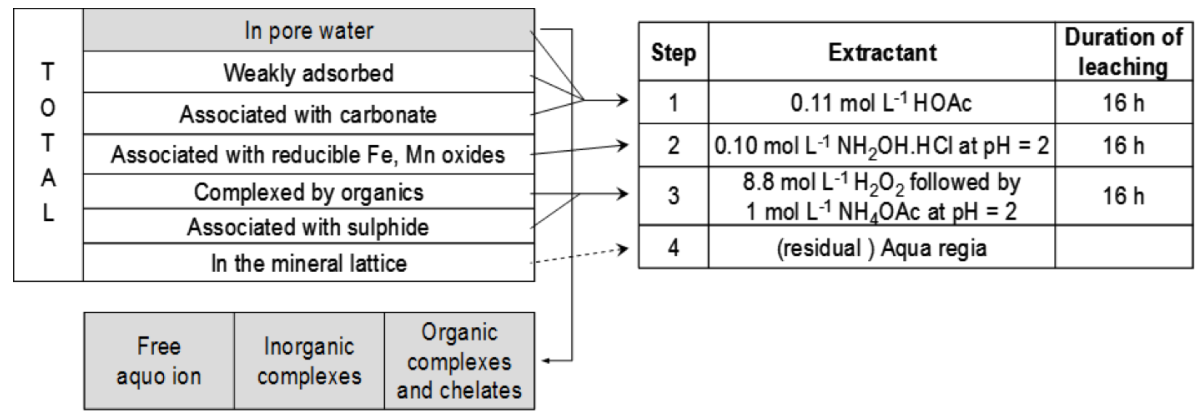

Scheme 1. Element fractions in aquatic sediment as classified by Kersten and Förstner [4], Caroli [3], and Tessier [5] (left-hand side) and the original BCR sequential extraction steps [6-8] (right-hand side)

and 2013: from 200/year to 700/year; according to related citations from 1000/year to 19,000 /year based on Thomson Reuters, Web of Science database. A primary risk assessment of heavy metal contamination in the soil/water/atmosphere system was based on the fractionation of metallic element content of environmental samples according to their environmental mobility. The term "fractionation" was recommended by the IUPAC in 2000 [2]. The mobility of an element according to the different solubilities of different binding classes can be estimated by solvents sequentially applied containing physico-chemically increasingly aggressive reagents [3,4]. In agricultural chemistry, the serial single step strategy (Fig.2), in environmental chemistry the strategy of sequential extraction has become dominant (Fig.3).

The first sequential extraction procedure for the characterisation of the mobility of heavy metals in aquatic sediments was developed by Tessier et al. [5], who classified the metal content of sediments according to the solubility and binding forms of metallic species as presented in Scheme 1.

Based on this essential work [5], numerous 5-8step sequential extraction schemes have been developed by which the original chemical structures (binding forms) are gradually dissolved and/or decomposed [9]. The complete duration of these procedures is 5-6 days, while the duration of the batch leaching steps is determined by a long setup time of solubility and heterogeneous chemical equilibria. The proposal for a $3(+1)$-step sequential extraction procedure issued by BCR in 1993 is a simplified version of the above-mentioned schemes [6], but it is still time-consuming and labourintensive.
As shown in Scheme 1, the water soluble, weakly adsorbed, and carbonate-associated metal fractions are extracted simultaneously by acetic acid in the first leaching step. In the second step, the metal fractions associated with reducible $\mathrm{Fe}$ and $\mathrm{Mn}$ oxides are produced after reduction by hydroxylamine. A fraction of metals coordinated to organic molecules and associated with sulphides is extracted after oxidation by $\mathrm{H}_{2} \mathrm{O}_{2}$ in the third step. In the extra step, the residual fraction can be obtained by means of digestion with aqua regia or $\mathrm{HNO}_{3} / \mathrm{H}_{2} \mathrm{O}_{2}$.

Re-adsorption of extracted metals during phase separation can lead to analyte losses. In the extracts, the high concentration of the reagent may cause strong matrix effects during spectrochemical element detection. The CRM 601 sediment reference material issued in 1997 has been certified for this procedure only for $\mathrm{Cd}, \mathrm{Cr}, \mathrm{Ni}, \mathrm{Pb}$, and $\mathrm{Zn}[7,8]$. During the analysis of the BCR 701 sediment materials, the original BCR procedure was modified to avoid analyte loss during the second leaching step due to $\mathrm{pH}$ instability [10-13]. However, this modification in BCR procedure may cause significant differences relative to previously obtained data. The BCR procedures in their original and modified versions were successfully applied to aquatic sediments and soils; however, soil CRM has not been issued for this procedure up to now [14-21].

It can be concluded that the Tessier-based fractionation procedures [5] are widely used for heavy metal contamination assessments in soils and aquatic sediments, but the realistic interpretation of these data requires standardisation. However, this has been hindered due to methodological problems of measurements and analysis [22-23]. These problems limiting the application of the BCR sequential 
Table 1. Overview of the cooperative research projects between Szent István University Gödöllő and the Technical University Košice

\begin{tabular}{|c|c|}
\hline $\begin{array}{l}\text { Limitations of the } \\
\text { BCR scheme }\end{array}$ & $\begin{array}{l}\text { Achievements by SZIE and TU Košice } \\
\text { research groups }\end{array}$ \\
\hline $\begin{array}{l}\text { Does not match the } \\
\text { natural mobilisation } \\
\text { pathways }\end{array}$ & $\begin{array}{l}\rightarrow \text { Better modelling of environmental mobility } \\
\text { by the application of } \mathrm{H}_{2} \mathrm{O} \text { and } \mathrm{H}_{2} \mathrm{O} / \mathrm{CO}_{2} \\
\text { solvents [24]. }\end{array}$ \\
\hline $\begin{array}{l}\text { Does not preserve } \\
\text { the intact species of } \\
\text { the sample }\end{array}$ & $\begin{array}{l}\rightarrow \text { Application of aqueous extractions for the } \\
\text { elaboration of biological tests [25]. }\end{array}$ \\
\hline $\begin{array}{l}\text { Time consuming } \\
(4-5 \text { days })\end{array}$ & $\begin{aligned} & \rightarrow \text { Acceleration of batch leaching by means of } \\
& \text { sonification [26]. } \\
& \rightarrow \text { Development of continuous flow operation in } \\
& \text { the supercritical fluid extractor for } \mathrm{CO}_{2}, \mathrm{H}_{2} \mathrm{O} \\
& \text { and } \mathrm{H}_{2} \mathrm{O} / \mathrm{CO}_{2} \text { solvents [24] }\end{aligned}$ \\
\hline \multicolumn{2}{|c|}{$\begin{array}{l}\text { Cross-contamination } \pi \\
\text { during operation and } \rightarrow \text { Reduction of operations and reagents } \\
\text { applied reagent }\end{array}$} \\
\hline \multicolumn{2}{|c|}{$\begin{array}{l}\text { Limited } \\
\text { applicability and } \\
\text { validation: }\end{array}$} \\
\hline $\begin{array}{l}\text { Validation and } \\
\text { available CRM only } \\
\text { for sediments }\end{array}$ & $\begin{array}{l}\rightarrow \text { Extension of the application to other matrices: } \\
\text { soils, gravitation dusts, biofilms, red mud, and } \\
\text { composts [26-30]. }\end{array}$ \\
\hline $\begin{array}{l}\text { Validation of the } \\
\text { procedure for } \mathrm{Cd} \text {, } \\
\mathrm{Cr}, \mathrm{Cu}, \mathrm{Ni}, \mathrm{Pb}, \mathrm{Zn}\end{array}$ & $\begin{aligned} \rightarrow & \text { Multi-elemental calibration and validation for } \\
& \text { different matrices and extracts [27]. }\end{aligned}$ \\
\hline $\begin{array}{l}\text { High reagent and } \\
\text { organic content of } \\
\text { the extracts }\end{array}$ & T \\
\hline
\end{tabular}

extraction procedure have initiated a cooperative research project between Szent István University Gödöllő and the Technical University Košice as summarised in Table 1.

The aim of the given study was the evaluation of changes in the environmental mobility of heavy metals at two polluted areas (Upper Tisza/2000-2001 and GödöllőIsaszeg lake system/1995-1998) by means of the repeated BCR fractionation of heavy metals in the sediments and soils [31-34]. A flexible, multi-elemental Inductively Coupled Plasma-Optical Emission (ICPOES) technique with a Charge-Coupled Device (CCD)detection system was employed instead of the formerly applied flame atomic absorption spectroscopy (FAAS). The latter had to be optimised for each analyte element individually. Hereby, the problems of the matrix-matched multi-elemental calibration of the ICP-OES method are described using different solvent applied from the BCR procedure. The validation of the calibration was controlled by the fractionation of the CRM 701 sample.

\section{Experimental}

\subsection{Elemental Analysis and Instrumentation}

For element detection in different extractant matrices, the HORIBA Jobin Yvon ACTIVA-M ICP-OE spectrometer was employed, which is able to record the entire UV-vis spectrum range by rapid scanning CCDdetection. It also makes possible the flexible analytical line selection for 75 elements. The wavelength scale calibration of recorded spectra is based on a reference line position set by the user. The C $193.026 \mathrm{~nm}$ line is proposed by the manufacturer in routine analytical applications. The instrument's scheme and technical

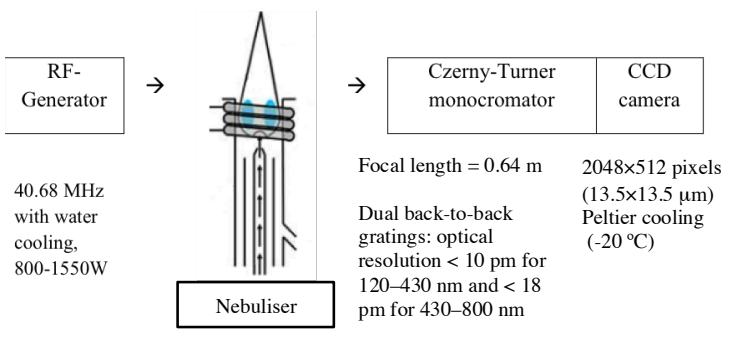

Figure 4. Scheme of the HORIBA Jobin Yvon ACTIVA-M ICP-OE spectrometer and relevant technical parameters

parameters are presented in Fig.4. Introduction of the sample can be performed by a concentric glass nebuliser and glass cyclone spray chamber fed by a 3-channel peristaltic pump.

\subsection{ICP-OES Operation Parameters}

The operation parameters of ICP-OES were selected on the basis of the manufacturer's manual proposed for multi-elemental analysis as follows:

- Incident power: $1000 \mathrm{~W}$,

- Plasma gas flow: $13.14 \mathrm{dm}^{3} \mathrm{~min}^{-1}$,

- Sheath gas flow: $0.32 \mathrm{dm}^{3} \mathrm{~min}^{-1}$,

- Nebuliser gas flow: $0.28 \mathrm{dm}^{3} \mathrm{~min}^{-1}$,

- Nebuliser gas pressure: 2.86 bar, and

- Nebuliser sample flow uptake: $0.85 \mathrm{~cm}^{3} \mathrm{~min}^{-1}$.

\subsection{Matrix Matched Calibration Solutions}

Amounts of $1 \mathrm{mg} \mathrm{dm}^{-3}$ (in $\mathrm{cc} \mathrm{HNO}_{3}$ ) mono-elemental $\mathrm{Cd}, \mathrm{Co}, \mathrm{Cr}, \mathrm{Cu}, \mathrm{Fe}, \mathrm{Mn}, \mathrm{Ni}, \mathrm{Pb}, \mathrm{V}$, and $\mathrm{Zn}$ (Précis Certified Standards for ICP Spectroscopy, HORIBA Scientific, France) standard solutions corresponding to 0,5 , and $20 \mathrm{mg} \mathrm{dm}^{-3}$ concentrations were pipetted into a $50 \mathrm{~cm}^{3}$ volumetric flask and then diluted by solvents applied in the BCR sequential extraction procedure:

- $\quad 1^{\text {st }}$ step: $0.11 \mathrm{M}$ acetic acid.

- $\quad 2^{\text {nd }}$ step: 0.1 M hydroxylamine-hydrochloride.

- $\quad 3^{\text {rd }}$ step: $1 \mathrm{M}$ ammonium acetate.

- $\quad$ extra step: $13 \mathrm{~g} / \mathrm{g}$ nitric acid.

\subsection{Analytical Lines}

The following analytical lines were selected according to the manufacturer's proposal for multi-elemental analysis:

- $\quad$ Cd $214.441 \mathrm{~nm}$

- $\quad$ Co $230.785 \mathrm{~nm}$

- $\quad$ Cr $205.571 \mathrm{~nm}$

- $\quad \mathrm{Cu} 324.754 \mathrm{~nm}$

- $\quad \mathrm{Fe} 259.940 \mathrm{~nm}$ and $240.489 \mathrm{~nm}$

- $\quad$ Mn $257.610 \mathrm{~nm}$

- $\quad$ Ni $222.296 \mathrm{~nm}$ (instead of $221.650 \mathrm{~nm}$ !)

- $\quad \mathrm{Pb} 220.353 \mathrm{~nm}$

- $\quad$ V $309.311 \mathrm{~nm}$

- $\quad$ Zn $213.857 \mathrm{~nm}$

In the first, second, and extra step, the wavelength readout started from the C $193.026 \mathrm{~nm}$ reference line. In the third step, the correct wavelength readout was only 
Table 2. The calibration lines $(\mathrm{y}=m \mathrm{x}+b$, at wave length $\lambda$ in $\mathrm{nm}$ ), correlation $R^{2}$ values, residual standard deviations (RSD), background equivalent concentrations (BEC in $\mu \mathrm{g} \mathrm{dm}^{-3}$ ), and detection limits $\left(C_{\mathrm{L}(3 \sigma)}\right.$ in $\left.\mu \mathrm{g} \mathrm{dm}^{-3}\right)$ obtained by a $0.11 \mathrm{M}$ acetic acid matrix.

\begin{tabular}{|c|c|c|c|c|c|c|c|}
\hline & $\lambda$ & $C_{\mathrm{L}(3 \sigma)}$ & BEC & $m$ & $b$ & $R^{2}$ & RSD \\
\hline $\mathrm{Cd}$ & 214.441 & 0.5 & 65 & 43778 & 2867 & & $1.1 \%$ \\
\hline & & & & & & & .5 \\
\hline & & & & & & & $9^{c}$ \\
\hline & & 0.2 & 121 & & & & $2.0 \%$ \\
\hline & & & 72 & & & & $.2 \%$ \\
\hline & & & 105 & & & & $1.8 \%$ \\
\hline & 222.296 & & 115 & & & & $2.0 \%$ \\
\hline & 220.3 & 3.5 & 17 & & 68.946 & & $0.3 \%$ \\
\hline & 30 & 0.6 & 34 & & & & $0.5 \%$ \\
\hline & 213.857 & 0.6 & 148 & 60540 & 8951 & 0.9998 & $3.2 \%$ \\
\hline
\end{tabular}

Table 4. The calibration lines $(\mathrm{y}=m \mathrm{x}+b$, at wave length $\lambda$ in $\mathrm{nm}$ ), correlation $R^{2}$ values, residual standard deviations (RSD), background equivalent concentrations (BEC in $\mu \mathrm{g} \mathrm{dm}^{-3}$ ), and detection limits $\left(C_{\mathrm{L}(3 \sigma)}\right.$ in $\left.\mu \mathrm{g} \mathrm{dm}^{-3}\right)$ obtained by a $1.00 \mathrm{M}$ ammoniumacetate matrix.

\begin{tabular}{lrrrrrrr}
\hline & \multicolumn{1}{c}{$\lambda$} & $C_{\mathrm{L}(3 \sigma)}$ & BEC & \multicolumn{1}{c}{$m$} & \multicolumn{1}{c}{$b$} & \multicolumn{1}{c}{$R^{2}$} & \multicolumn{1}{c}{ RSD } \\
\hline $\mathrm{Cd}$ & 214.441 & 0.6 & 57 & 70051 & -4008.3 & 1.0000 & $1.0 \%$ \\
$\mathrm{Co}$ & 230.785 & 1.4 & 2 & 54840 & -119.26 & 1.0000 & $0.03 \%$ \\
$\mathrm{Cr}$ & 205.571 & 1.2 & 21 & 25579 & 546.52 & 1.0000 & $0.3 \%$ \\
$\mathrm{Cu}$ & 324.754 & 2.5 & 213 & 151053 & 32156 & 0.9994 & $3.5 \%$ \\
$\mathrm{Fe}$ & 259.940 & 15.8 & 160 & 258243 & 41379 & 1.0000 & $0.6 \%$ \\
$\mathrm{Mn}$ & 257.610 & 0.4 & 21291505 & 2013 & 1.0000 & $0.02 \%$ \\
$\mathrm{Ni}$ & 222.296 & 2.3 & 17 & 9902 & -170.25 & 1.0000 & $0.3 \%$ \\
$\mathrm{~Pb}$ & 220.353 & 3.5 & 148 & 5905.2 & -874.08 & 0.9997 & $2.6 \%$ \\
$\mathrm{~V}$ & 309.311 & 1.4 & 85 & 312207 & 26636 & 0.9999 & $1.4 \%$ \\
$\mathrm{Zn}$ & 213.857 & 14.5 & 33 & 79775 & 2643.2 & 0.9968 & $1.9 \%$ \\
\hline
\end{tabular}

Table 5. The calibration lines $(\mathrm{y}=m \mathrm{x}+b$, at wave length $\lambda$ in $\mathrm{nm}$ ), correlation $R^{2}$ values, residual standard deviations (RSD), background equivalent concentrations (BEC in $\mu \mathrm{g} \mathrm{dm}^{-3}$ ), and detection limits $\left(C_{\mathrm{L}(3)}\right.$ in $\left.\mu \mathrm{g} \mathrm{dm}^{-3}\right)$ obtained by a $13 \mathrm{~g} / \mathrm{g}$ nitric acid and hydrogen peroxide matrix.

\begin{tabular}{lrrrrrrr}
\hline & $\lambda$ & $C_{\mathrm{L}(3 \sigma)}$ & BEC & \multicolumn{1}{c}{$m$} & \multicolumn{1}{c}{$b$} & \multicolumn{1}{c}{$R^{2}$} & $\mathrm{RSD}$ \\
\hline $\mathrm{Cd}$ & 214.441 & 0.4 & 392 & 74770 & 29293 & 0.9980 & $6.6 \%$ \\
$\mathrm{Co}$ & 230.785 & 3.5 & 319 & 50151 & 16009 & 0.9986 & $5.4 \%$ \\
$\mathrm{Cr}$ & 205.571 & 1.7 & 328 & 23088 & 7580.7 & 0.9986 & $5.5 \%$ \\
$\mathrm{Cu}$ & 324.754 & 0.9 & 343 & 104399 & 35859 & 0.9985 & $5.6 \%$ \\
$\mathrm{Fe}$ & 259.940 & 0.7 & 219 & 216961 & 47594 & 0.9995 & $3.2 \%$ \\
$\mathrm{Mn}$ & 257.610 & 0.5 & 211 & 1056725 & 222941 & 1.0000 & $3.6 \%$ \\
$\mathrm{Ni}$ & 222.296 & 0.5 & 320 & 9282.3 & 2974.7 & 0.9987 & $5.4 \%$ \\
$\mathrm{~Pb}$ & 220.353 & 8.7 & 265 & 6483.7 & 1717.4 & 0.9991 & $4.4 \%$ \\
$\mathrm{~V}$ & 309.311 & 0.7 & 54 & 256488 & 13775 & 1.0000 & $0.9 \%$ \\
$\mathrm{Zn}$ & 213.857 & 17.3 & 517 & 87624 & 45308 & 0.9968 & $8.3 \%$ \\
\hline
\end{tabular}

possible when the readout started from the Ar $404.442 \mathrm{~nm}$ reference line due to the use of $1 \mathrm{M}$ ammonium acetate solution.

\subsection{Validation}

For validation of the CRM 701 sediment, the reference sample was applied. The fractionation of its element content was performed according to the modified BCR proposal [10-13] in triplicates. For the extraction of the
Table 3. The calibration lines $(\mathrm{y}=m \mathrm{x}+b$, at wave length $\lambda$ in $\mathrm{nm}$ ), correlation $R^{2}$ values, residual standard deviations (RSD), background equivalent concentrations (BEC in $\mu \mathrm{g} \mathrm{dm}^{-3}$ ), and detection limits $\left(C_{\mathrm{L}(3 \sigma)}\right.$ in $\left.\mu \mathrm{g} \mathrm{dm}^{-3}\right)$ obtained by a $0.10 \mathrm{M}$ hydroxylamine-hydrochloride matrix.

\begin{tabular}{lcrrrrrr}
\hline & $\lambda$ & $C_{\mathrm{L}(3 \sigma)}$ & $\mathrm{BEC}$ & \multicolumn{1}{c}{$m$} & \multicolumn{1}{c}{$b$} & \multicolumn{1}{c}{$R^{2}$} & $\mathrm{RSD}$ \\
\hline $\mathrm{Cd}$ & 214.441 & 0.9 & 87 & 47809 & -4145.2 & 0.9999 & $1.5 \%$ \\
$\mathrm{Co}$ & 230.785 & 1.4 & 19 & 44538 & -856.49 & 1.0000 & $0.3 \%$ \\
$\mathrm{Cr}$ & 205.571 & 1.4 & 14 & 18911 & -258.4 & 1.0000 & $0.2 \%$ \\
$\mathrm{Cu}$ & 324.754 & 0.9 & 72 & 163871 & 11765 & 1.0000 & $1.0 \%$ \\
$\mathrm{Fe}$ & 259.940 & 0.3 & 1 & 204879 & 236.82 & 1.0000 & $0.2 \%$ \\
$\mathrm{Mn}$ & 257.610 & 0.2 & 63 & 911472 & 57160 & 0.9999 & $1.1 \%$ \\
$\mathrm{Ni}$ & 222.296 & 3.7 & 63 & 7505.8 & 471.04 & 1.0000 & $1.0 \%$ \\
$\mathrm{~Pb}$ & 220.353 & 3.9 & 4 & 4375.2 & -17.636 & 1.0000 & $0.2 \%$ \\
$\mathrm{~V}$ & 309.311 & 0.2 & 58 & 260057 & -15164 & 1.0000 & $1.0 \%$ \\
$\mathrm{Zn}$ & 213.857 & 1.5 & 45 & 63846 & 2845.5 & 1.0000 & $0.5 \%$ \\
\hline
\end{tabular}

Table 6. Results for the BCR-fractionation of element content (in $\mu \mathrm{g} \mathrm{dm}^{-3}$ ) of the CRM 701 sample.

\begin{tabular}{|c|c|c|c|c|}
\hline \multicolumn{2}{|c|}{ steps } & measured & certified & recovery \\
\hline \multirow{10}{*}{$1^{\text {st }}$} & $\mathrm{Cd}$ & $6.45 \pm 0.07$ & $7.34 \pm 0.35$ & $88 \%$ \\
\hline & Co & $1.68 \pm 0.06$ & & \\
\hline & $\mathrm{Cr}$ & $1.88 \pm 0.08$ & $2.26 \pm 0.16$ & $83 \%$ \\
\hline & $\mathrm{Cu}$ & $44.93 \pm 0.25$ & $49.3 \pm 1.7$ & $91 \%$ \\
\hline & $\mathrm{Fe}$ & $57.74 \pm 2.53$ & & \\
\hline & Mn & $133.17 \pm 6.52$ & & \\
\hline & $\mathrm{Ni}$ & $12.52 \pm 0.34$ & $15.4 \pm 0.9$ & $81 \%$ \\
\hline & $\mathrm{Pb}$ & $1.92 \pm 0.19$ & $3.18 \pm 0.21$ & $60 \%$ \\
\hline & V & $0.06 \pm 0.23$ & & \\
\hline & $\mathrm{Zn}$ & $160.07 \pm 4.22$ & $205 \pm 6$ & $78 \%$ \\
\hline \multirow{10}{*}{$2^{\text {nd }}$} & $\mathrm{Cd}$ & $3.96 \pm 0.08$ & $3.77 \pm 0.28$ & $105 \%$ \\
\hline & Co & $2.71 \pm 0.03$ & & \\
\hline & $\mathrm{Cr}$ & $26.53 \pm 0.78$ & $45.7 \pm 2$ & $58 \%$ \\
\hline & $\mathrm{Cu}$ & $87.61 \pm 0.81$ & $124 \pm 3$ & $71 \%$ \\
\hline & $\mathrm{Fe}$ & $5648 \pm 50$ & & \\
\hline & Mn & $106.99 \pm 2.90$ & & \\
\hline & $\mathrm{Ni}$ & $19.55 \pm 0.35$ & $26.6 \pm 1.3$ & $73 \%$ \\
\hline & $\mathrm{Pb}$ & $92.17 \pm 2.24$ & $126 \pm 3$ & $73 \%$ \\
\hline & V & $8.50 \pm 0.09$ & & \\
\hline & $\mathrm{Zn}$ & $98.77 \pm 2.27$ & $114 \pm 5$ & $87 \%$ \\
\hline \multirow{10}{*}{$3^{\text {rd }}$} & $\mathrm{Cd}$ & $1.17 \pm 0.01$ & $0.27 \pm 0.06$ & $435 \%$ \\
\hline & Co & $1.80 \pm 0.08$ & & \\
\hline & $\mathrm{Cr}$ & $196.4 \pm 8.24$ & $143 \pm 7$ & $137 \%$ \\
\hline & $\mathrm{Cu}$ & $63.59 \pm 2.92$ & $55.2 \pm 4$ & $115 \%$ \\
\hline & $\mathrm{Fe}$ & $4652 \pm 133$ & & \\
\hline & Mn & $43.65 \pm 1.25$ & & \\
\hline & $\mathrm{Ni}$ & $24.49 \pm 0.35$ & $15.3 \pm 0.9$ & $160 \%$ \\
\hline & $\mathrm{Pb}$ & $60.14 \pm 0.82$ & $9.3 \pm 2$ & $647 \%$ \\
\hline & V & $5.86 \pm 0.21$ & & \\
\hline & $\mathrm{Zn}$ & $66.44 \pm 0.62$ & $45.7 \pm 4$ & $145 \%$ \\
\hline \multirow{10}{*}{ extra } & $\mathrm{Cd}$ & $1.38 \pm 0.01$ & & \\
\hline & Co & $7.63 \pm 0.18$ & & \\
\hline & $\mathrm{Cr}$ & $101.12 \pm 4.79$ & & \\
\hline & $\mathrm{Cu}$ & $49.48 \pm 1.92$ & & \\
\hline & $\mathrm{Fe}$ & $24988 \pm 805$ & & \\
\hline & $\mathrm{Mn}$ & $302.9 \pm 3.7$ & & \\
\hline & $\mathrm{Ni}$ & $44.50 \pm 1.36$ & & \\
\hline & $\mathrm{Pb}$ & $12.77 \pm 0.30$ & & \\
\hline & V & $40.30 \pm 0.67$ & & \\
\hline & $\mathrm{Zn}$ & $127.12 \pm 1.36$ & & \\
\hline
\end{tabular}

residual fraction in the extra step and for the determination of the pseudo total element content microwave supported cc $\mathrm{HNO}_{3} / \mathrm{H}_{2} \mathrm{O}_{2}$ digestion was applied. 
Table 7. Comparison of the summarised element content (in $\mathrm{mg} \mathrm{kg}^{-1}$ ) extracted in BCR steps 1-3 using certified values for the CRM 701 sample.

\begin{tabular}{lccc}
\hline & steps 1-3 & certified & recovery \\
\hline $\mathrm{Cd}$ & 11.58 & 11.38 & $102 \%$ \\
$\mathrm{Co}$ & 6.19 & & \\
$\mathrm{Cr}$ & 224.8 & 191.0 & $118 \%$ \\
$\mathrm{Cu}$ & 196.1 & 228.5 & $86 \%$ \\
$\mathrm{Fe}$ & 10358 & & \\
$\mathrm{Mn}$ & 283.8 & & \\
$\mathrm{Ni}$ & 56.6 & 57.3 & $99 \%$ \\
$\mathrm{~Pb}$ & 154.2 & 138.5 & $111 \%$ \\
$\mathrm{~V}$ & 14.42 & & \\
$\mathrm{Zn}$ & 325.3 & 364.7 & $89 \%$ \\
\hline
\end{tabular}

\section{Results and Analysis}

The parameters of analytical calibration lines, background equivalent concentrations (BEC) and detection limits $\left(C_{\mathrm{L}(3 \sigma)}\right)$ obtained by different extraction matrices are summarised in Tables 2-5. It can be established that the extraction matrix solvents significantly influence the sensitivity $(B)$ values for all elements in the order of $B\left(3^{\text {rd }}\right)>B($ extra $)>B\left(2^{\text {nd }}\right)$ $>\mathrm{B}\left(1^{\mathrm{st}}\right)$ as a function of steps taken. With the exception of some outliers, the residual standard deviation values are in the range of $1-2 \%$ and the detection limits are in the range of $0.5-2 \mu \mathrm{g} \mathrm{dm}^{-3}$. The outliers for $\mathrm{Pb}, \mathrm{Zn}$ and $\mathrm{Fe}$ in certain matrices refer to neglected spectral interferences.

The results of the fractionation of the element content of the CRM 701 sample by applying the matrix matched calibration for determining the element contents in the extracts are summarised and compared with the certified and pseudo-total values in Tables 6-8. It can be seen that the metal content in BCR Steps 1-3 shows an acceptable agreement $\left(<\mathrm{mg} \mathrm{dm}^{-3}\right)$ with certified values. In the individual steps, there are larger differences for elements than are acceptable: $1^{\text {st }}$ step: $\mathrm{Pb} ; 2^{\text {nd }}$ step: $\mathrm{Cr}, \mathrm{Cu}$, and $\mathrm{Pb} ; 3^{\text {rd }}$ step: $\mathrm{Cd}, \mathrm{Ni}, \mathrm{Pb}$, and $\mathrm{Zn}$.

\section{Conclusion}

Based on the results presented here, it can be concluded that the extractants applied in the BCR sequential extraction procedure cause significant matrix effects even in the case of matrix-matched multi-elemental calibration of the ICP-OES determination of element content. The sensitivities were strongly influenced by the extractant media, therefore, a much higher incident power was required to eliminate these differences to ensure conditions that are more robust. The recoveries of certified values of the CRM 701 sample were within the acceptable range when the summary of extracted amounts in the BCR Steps 1-3 was compared. Significant differences occurring in individual extraction steps between the measured and certified values refer to neglected spectral interferences. This requires a detailed study utilising the flexible line
Table 8. Comparison of the summarised element content (in $\mathrm{mg} \mathrm{kg}^{-1}$ ) extracted in BCR steps 1-3 using pseudo-total values.

\begin{tabular}{lccc}
\hline & steps 1-3+extra & pseudo-total & recovery \\
\hline $\mathrm{Cd}$ & 12.96 & 9.63 & $135 \%$ \\
$\mathrm{Co}$ & 13.81 & 10.68 & $129 \%$ \\
$\mathrm{Cr}$ & 325.9 & 290.5 & $112 \%$ \\
$\mathrm{Cu}$ & 245.6 & 257.7 & $95 \%$ \\
$\mathrm{Fe}$ & 35323 & 31285 & $113 \%$ \\
$\mathrm{Mn}$ & 586.4 & 567.7 & $103 \%$ \\
$\mathrm{Ni}$ & 101.0 & 77.2 & $131 \%$ \\
$\mathrm{~Pb}$ & 167.0 & 158.2 & $106 \%$ \\
$\mathrm{~V}$ & 54.68 & 39.20 & $140 \%$ \\
$\mathrm{Zn}$ & 452.3 & 417.7 & $108 \%$ \\
\hline
\end{tabular}

selection possibility offered by the HORIBA Jobin Yvon ACTIVA-M instrument.

\section{Acknowledgement}

This work was supported by the Hungarian Scientific Research Fund (OTKA 108558), KTIA AIK-12-1-20120012 and the Research Centre of Excellence - 85265/2014/TUDPOL.

\section{REFERENCES}

[1] Gunn, A.M.; Winnard, D.A.; Hunt, D.T.E. : Trace metal speciation in sediment and soils, in Metal speciation: Theory, analysis and application, Eds.: Kramer, J.R.; Allen, H.E. (Lewis Publications, Boca Raton, FL, USA) 1988 ISBN 08737114089780873711401

[2] Templeton, D.M.; Ariese, F.; Cornelis, R.; Danielsson, L.G.; Muntau, H.; van Leeuwen, H.P.; Lobinski, R.: Guidelines for terms related to chemical speciation and fractionation of elements. Definitions, structural aspects, and methodological approaches, Pure Appl. Chem., 2000 72, 1453-1470 10.1351/pac200072081453

[3] Caroli, S.: Element speciation in bioorganic chemistry (Wiley, New York, USA) 1996 ISBN 0471-57641-7

[4] Kersten, M.; Förstner, M.: Speciation of trace metals in sediments and combustion waste. In Chemical speciation in the environment, Eds.: Ure, A.M.; Davidson, C.M. (Blackie Academic and Professional, London, U.K.) 1995, pp. 237 275

[5] Tessier, A.; Campbell, P.G.C.; Bisson, M.: Sequential extraction procedure for the speciation of particulate trace metals, Anal. Chem., 1979, 51, 844-851 10.1021/ac50043a017

[6] Ure, A.M.; Quevauviller, Ph.; Muntau, H.; Griepink, B.: Speciation of heavy-metals in soils and sediments - an account of the improvement and harmonization of extraction techniques undertaken under the auspices of the BCR of the Commission of the European Communities, Int. J. Envir. Anal. Chem., 1993 51, 135-151 10.1080/0306731908027619 
[7] Quevauviller, P.; Rauret, G.; López-Sánchez, J.F.; Rubio, R.; Ure, A.; Muntau, H.: Certification of trace metal extractable contents in a sediment reference material (CRM 601) following a threestep sequential extraction procedure, Sci. Total Environ., 1997 205, 223-234 10.1016/S00489697(97)00205-2

[8] López-Sánchez, J.F.; Sahuquillo, A.; Fiedler, H.D.; Rubio, R.; Rauret, G.; Muntau, H.; Quevauviller, Ph.: CRM 601, a stable material for its extractable content of heavy metals, Analyst, 1998 123, 16751677 10.1039/A8022720J

[9] Gleyzes, C.; Tellier, S.; Astruc, M.: Fractionation studies of trace elements in contaminated soils and sediments: a review of sequential extraction procedures, Trends Anal. Chem., 2002 21, 451-467 10.1016/S0165-9936(02)00603-9

[10] Rauret, G.; López-Sánchez, J.F.; Sahuquillo, A.; Rubio, R.; Davidson, C.; Ure, A.; Quevauviller, $\mathrm{Ph} .:$ Improvement of the BCR three step sequential extraction procedure prior to the certification of new sediment and soil reference materials, $J$. Envir. Monit., 1999 1, 57-61 10.1039/A807854H

[11] Sahuquillo, A.; López-Sánchez, J.F.; Rubio, R.; Rauret, G.; Thomas, R.P.; Davidson, C.M.; Ure, A.M.: Use of a certified reference material for extractable trace metals to assess sources of uncertainty in the BCR three-stage sequential extraction procedure, Anal. Chim. Acta, 1999382 , 317-327 10.1016/S0003-2670(98)00754-5

[12] Pueyo, M.; Rauret, G.; Lück, D.; Yli-Halla, M.; Muntau, H.; Quevauviller, Ph.; López-Sánchez, J.F.: Certification of the extractable contents of $\mathrm{Cd}$, $\mathrm{Cr}, \mathrm{Cu}, \mathrm{Ni}, \mathrm{Pb}$ and $\mathrm{Zn}$ in a freshwater sediment following a collaboratively tested and optimised three-step sequential extraction procedure, J. Envir. Monit., 2001 3, 243-250 10.1039/b01025k

[13] Rauret, G.; López-Sánchez, J.F.; Lück, D.; YliHalla, M.; Muntau, H.; Quevauviller, Ph.: Certification of the extractable contents of $\mathrm{Cd}, \mathrm{Cr}$, $\mathrm{Cu}, \mathrm{Ni}, \mathrm{Pb}$ and $\mathrm{Zn}$ in a freshwater sediment following a collaboratively tested and optimised three-step sequential extraction procedure, European Commission BCR information reference materials BCR 701, 2001 ISBN 92-894-0755-7

[14] Sahuquillo, A.; Rigol, A.; Rauret, G.: Overview of the use of leaching/extraction tests for risk assessment of trace metals in contaminated soils and sediments, Trends Anal. Chem., 2003 22, 152159 10.1016./S0165-9936(03)00303-0

[15]Žemberyová, M.; Barteková, J.; Hagarová, I.: The utilization of modified BCR three-step sequential extraction procedure for the fractionation of $\mathrm{Cd}$, $\mathrm{Cr}, \mathrm{Cu}, \mathrm{Ni}, \mathrm{Pb}$ and $\mathrm{Zn}$ in soil reference materials of different origins, Talanta, 2006 70, 973-978 10.1016/j.talanta.2006.05.057

[16] Kubová, J.; Streško, V.; Bujdoš, M.; Matúš, P.; Medved, J.: Fractionation of various elements in CRMs and in polluted soils, Anal. Bioanal. Chem., 2004 379, 108-114 10.1007/s00214-004-2505-5
[17] Kubová, J.; Matúš, P.; Hagarová, I.; Bujdoš, M.; Medved, J.: Utilization of optimised BCR threestep sequential and dilute $\mathrm{HCl}$ single extraction procedures for soil-plant metal transfer predictions in contaminated lands, Talanta, 2008 75, 11101122 10.1016/j.talanta.2008.01.002

[18] Konradi, E.A.; Frentiu, T.; Ponta, M.; Cordos, E.: Use of sequential extraction to assess metal fractionation in soils from Bozanta Mare, Romania, Acta Univers. Cibiniensis Ser. F Chemia, 2005 8(2), 5-12 http://saiapm.ulbsibiu.ro/rom/cercetare/art/art2.pdf

[19] Okoro, H.K.; Fatoki, O.S.; Adekola, F.A.; Ximba, B.J.; Snyman, R.G.: A review of sequential extraction procedures for heavy metals speciation in soil and sediments, Open Access Sci. Rep., 2012 1(3): 181 10.4172/scientificreports.181

[20] Jena, V.; Gupta, S.; Dhundhel, R.S.; Matic, N.; Frančišković Bilinski, S.; Devic, N.: Determination of total heavy metal by sequential extraction from soil. Int. J. Res. Environ. Sci. Technol., 2013 3(1), 35-38 ISSN 2249-9695

[21]Zimmerman, A.J.; Weindorf, D.C.: Heavy metal and trace metal analysis in soil by sequential extraction: A review of procedures. Int. J. Anal. Chem., 2010 7, Article ID 387803 $10.1155 / 2010 / 387803$

[22]Zimmerman, A.J.; Weindorf, D.C.: Heavy metal and trace metal analysis in soil by sequential extraction: A review of procedures, Int. J. Anal. Chem., 2010 7, 387803 10.1155/2010/387803

[23] Dabek-Zlotorzynska, E.; Kelly, M.; Chen, H.; Chakrabarti, C.L.: Application of capillary electrophoresis combined with a modified BCR sequential extraction for estimating of distribution of selected trace metals in $\mathrm{PM}_{2.5}$ fractions of urban airborne particulate matter, Chemosphere, 2005 58, 1365-1376 10.1016/j.chemosphere.2004.09.082

[24] Heltai, Gy.; Fehér, B.; Percsich, K.; Barabás, B.; Fekete, I.: Application of sequential extraction with supercritical $\mathrm{CO}_{2}$, subcritical $\mathrm{H}_{2} \mathrm{O}$, and an $\mathrm{H}_{2} \mathrm{O} / \mathrm{CO}_{2}$ mixture for estimation of environmentally mobile heavy metal fractions in sediments, Anal. Bioanal. Chem., 2002 373(8), 863-866 10.1007/s00216-0021388-6

[25] Heltai, Gy.: Chemical interpretation of a new sequential extraction scheme based on supercritical $\mathrm{CO}_{2}$ and subcritical $\mathrm{H}_{2} \mathrm{O}$ solvents, Bull. Szent István University, 2005, 107-122

[26] Rusnák, R.; Halász, G.; Horváth, M.; Remeteiová, D.: Preliminary results on the intensification of the BCR sequential extraction with sonication for sediments, soils, and gravitation dust sediment samples, Toxicol. Environment. Chem., 2010 92(3), 443-452 10.1080/02772240903300139

[27] Horváth, M.; Halász, G.; Kucanová, E.; Kuciková, B.; Fekete, I.; Remeteiová, D.; Heltai, Gy.; Flórián, K.: Sequential extraction studies on aquatic sediment and biofilm samples for the assessment of heavy metal mobility, Microchem.J., 2013 107(3), 121-125 10.1016/j.microc.2012.05.024 
[28]Flórián, K.; Matherny, M.; Nickel, H.; Pliešovská, N.; Uhrinová, K.: Environmental characteristics of the atmosphere of residential agglomerations - I. Dustiness of the agglomerations, Chem. Pap., 2003 57(5), 369-373

[29]Flórián, K.; Matherny, M.; Nickel, H.; Pliešovská, N.; Uhrinová, K.: Environmental characteristics of the atmosphere of residential agglomerations - II. Main, minor, and trace elements in the gravitation dust sediments, Chem. Pap., 2003 57(5), 374-381

[30]Remeteiová, D.; Sminčáková, E.; Flórián, K.: Study of the chemical properties of gravitation dust sediments, Microchim. Acta, 2007 156(1-2), 109_ 113 10.1007/s00604-006-0603-0

[31] Shiowatana, J.; Tantidanai, N.; Noobkaew, S.; Nacapricha, D.: A novel continuous-flow sequential extraction procedure for metal speciation in solids, J. Environ. Qual., 2001 30, 1195-1205 10.2134/jeq2001.3041195x
[32] Heltai, Gy.; Fekete, I.; Gémesi, Z.; Percsich, K.; Flórián, K.; Tarr, Zs. : Environmental evaluation of a local lake chain affected by wastewater by means of spectrochemical analytical methods, Microchem. J., 1998 59, 125-135 10.1006/mchj.1998.1574

[33] Győri, Z.; Alapi, K.; Szilágyi, Sz.: Effects of heavy metal on floodplain soils and pastures of the River Tisza, Hungary I. In natural attenuation of metals along the Tisza river-floodplain-wetlands continuum (University of Debrecen, Debrecen, Hungary) 2003, pp. 146-160 ISBN: 9634727263

[34] Győri, Z.; Alapi, K.; Sipos, P.; Zubor, Á.: Effects of heavy metal on floodplain soils and pastures of the River Tisza, Hungary II. In natural attenuation of metals along the Tisza river-floodplainwetlands continuum (University of Debrecen, Debrecen, Hungary) 2003, pp. 161-163 ISBN: 963 4727263 


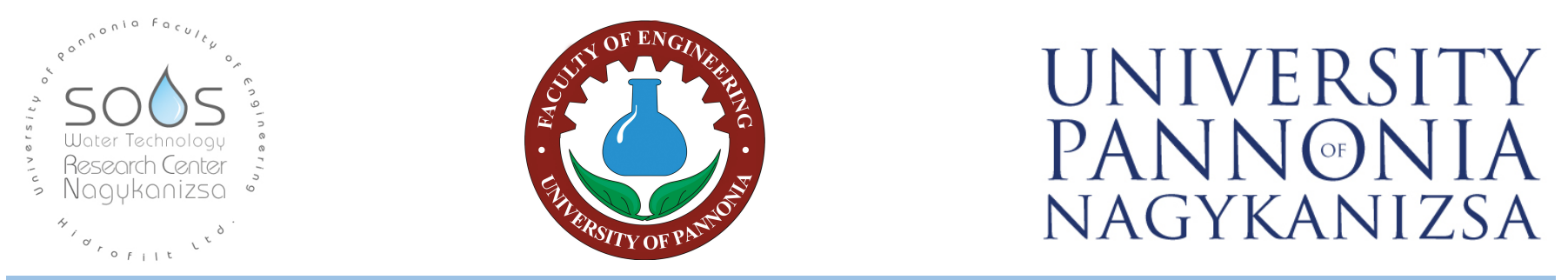

About water for water -

WATER AND WASTEWATER TREATMENT SYSTEM OPERATING ENGINEER

postgraduate specialist training course with the co-operation of one of Hungary's

oldest historical universities and a company of international reputation

\author{
"WATER IS ESSENTIAL FOR LIFE ON EARTH AS MUCH AS \\ GOOD QUALITY EDUCATION IS FOR PROFESSIONAL EXPERTS."
}

The University of Pannonia Faculty of Engineering and the Nagykanizsa Campus along with HIDROFILT Water and Wastewater Treatment Ltd. are offering a postgraduate course programme in water and wastewater treatment.

Hungary has long been recognised as a great water power with a historical background in the field of water treatment and purification. The University of Pannonia has a long tradition of academic excellence based on the training of engineering specialists for industry and the economy. The Faculty of Engineering and the Nagykanizsa Campus of the University of Pannonia are committed to forging partnerships with industry. Our aim is to create a generation of engineers that will take a lead in the development of innovative and sustainable technologies.

The Water and Wastewater Treatment System Operation Programme is designed for those engineering and non-engineering graduates who wish to pursue a career in water and wastewater treatment.

The Nagykanizsa Campus offers a wide spectrum of quality programmes that not only enhance students' professional development, but also familiarise them with the natural and historic values of Hungary. Mentors will assist students in organising their educational programmes and review their theses. Each student benefits from the opportunity of acquiring a broad range of transferable skills towards their future career within an outstanding academic environment.

Duration of the course programme: 2 semesters/4 months.

Theoretical training in water and wastewater treatment technologies is provided by the University of Pannonia, and Hidrofilt Ltd. Practical work and laboratory sessions will be carried out with the help of professional mentors from Hidrofilt Ltd. The Faculty of Engineering provides course materials and notes that are included in the package. Competencies to be acquired:

- Classification and adequate employment of the theoretical knowledge and practical methods acquired in the field; independent decision-making and development skills.

- Ability to analyse the qualitative and quantitative characteristics of water and wastewater; creating, implementing and assessing measurement plans.

- Optimal employment and management of state-of-the-art water and wastewater treatment technologies.

- Operating, planning and managing water supply and water and wastewater treatment technologies.

- Knowledge and employment of quality assurance and technical control.

- Analytical skills in technical, economical, and social relations in water and wastewater treatment.

- Evaluation of conceptions and programmes regarding water on national and international levels.

The qualification provides skills and abilities that can be employed profitably not only on a national but also on an international level. Graduates are able to design and implement investments related to water and wastewater treatment and maintain systems in operation.

We offer a practice-oriented training programme in addition to high-quality academic education. Those participating in the study programme gain state-of-the-art knowledge that fits the needs of the market and acquire the most advanced water purification technologies applied in the industry.

Information available from: info@sooswrc.hu 